\title{
プレス加工法によるタリウム系テープ状 線材の高電流密度化
}

岡田 道哉, 湯浅 豊隆, 松本 俊美, 加茂 友一

相原 勝蔵, 清藤 雅宏*, 松田 臣平

（株）日立製作所日立研究所 日立市久慈町 4026

* 日立電線(株)金属研究所 土浦市木田余町 3550

(1990 年 3 月 7 日受理)

Development of Tl-(Ba/Sr)-Ca-Cu-O Tape-Shaped Wire Prepared by the Drawing-Rolling-Pressing Method

Michiya OKada, Toyotaka Yuasa, Toshimi Matsumoto, Tomoichi Kamo, Katsuzo AiHARA, Masahiro SEIDO* and Shinpei MAtsuda

Hitachi Research Laboratory of Hitachi Ltd., Hitachi, Ibaraki 319-12

* Metal Research Laboratory of Hitachi Cable Ltd., Tsuchiura, Ibaraki 300

(Received March 7, 1990)

\section{Synopsis:}

Metal-sheathed tapes with $\mathrm{Tl}-(\mathrm{Ba} / \mathrm{Sr})-\mathrm{Ca}-\mathrm{Cu}-\mathrm{O}$ (TBSCCO) system were fabricated using the drawing-rolling method combined with a pressing process in order to improve the weak link properties. The $T_{\mathrm{c}}$ 's of the tapes were measured to be $115 \pm 2 \mathrm{~K}$. The $J_{\mathrm{c}}$ was measured at various temperatures and in the presence of external magnetic fields. At $77 \mathrm{~K}$ the $J_{\mathrm{c}}$ was $15,900 \mathrm{~A} / \mathrm{cm}^{2}$ in the absence of magnetic field and slightly above $1,000 \mathrm{~A} / \mathrm{cm}^{2}$ at $1 \mathrm{~T}$. The effect of magnetic field becomes much smaller at the lower temperature, for example at $20 \mathrm{~K}$ the $J_{\mathrm{c}}$ was $8,000 \mathrm{~A} / \mathrm{cm}^{2}$ at $1 \mathrm{~T}$. A tape fabricated by the drawing-rolling method without the post-pressing process gave the $J_{\mathrm{c}}$ of about $2,000 \mathrm{~A} / \mathrm{cm}^{2}$ at $20 \mathrm{~K}$ and $1 \mathrm{~T}$. An effect of the pressing is thought to be the densification of TBSCCO core. Another effect which could be thought is the orientation of TBSCCO crystals through the pressing process, although the orientation is not clear in the SEM observation. The relatively higher $J_{\mathrm{c}}$ is thought to be caused by an improved junction between grain boundaries and by an introduction of pinning center from various defects and unknown crystal phases. We believe that there exists flux pinning center in the TBSCCO system which is not yet identified.

\section{1. 緒言}

酸化物系高温超電導体の発見以来 ${ }^{1 \sim 3)}$, 液体窒素温 度で動作する超電導応用機器の開発を目的として, エ レクトロニクス・デバイスを指向した薄膜化，执よび 強電応用を目的とした線材化技術の開発が，各方面で 精力的に進められてきた。現在, 線材化技術のなかで は, その高電流密度化が最大の課題となっている4)。

酸化物超電導体の液体窒素温度に扣忷る臨界電流密 度 $J_{\mathrm{c}}$ は, 応用に供するためには, 磁場中で少なくと あ $10^{4} \sim 10^{5} \mathrm{~A} / \mathrm{cm}^{2}$ が必要である。単結晶や配向した 薄膜ではこの值を超えているものがあるが5,6), バル
クの多結晶体や線材においてこの值を超えた例はこれ までにない。この原因は, 高温超電導体の結晶粒界が 超電導の弱い結合状態にあって, 僅かの外部磁場によ って粒界部分の超電導が破壊されることが主因である と考光られている7)。また, 液体窒素温度に怙いては 超電導状態で量子化された磁束線（フラクソイド）が ピン止めされにくく，このため生ずるフラックスクリ ープによって高い臨界電流密度が磁場中では得られに くい(8)。したがって, 高温超電導線材の実用化のため には, 粒界での弱結合とフラックスクリープの両者を 同時に克服する必要がある。

われわれは, 高温超電導体の発見以来, 一貫して粉 
末法による線材化技術の開発を行ってきた ${ }^{9219)}$ 。線材 の高電流密度化に関しては, いち早く線引き一圧延法 を提案し ${ }^{9)}$, 現在ではこの線引き一圧延加工法は, 線 材の高電流密度化の最も一般的な方法として広く用い られるようになった。酸化物超電導線材は, 最近では, 液体窒素温度では比較的低磁場用で, また, 液体へリ ウム温度では20 T以上の高磁場用の線材として注目 されつつある。その一方で, 臨界電流密度は零磁場で $10^{4} \mathrm{~A} / \mathrm{cm}^{2}$ 程度であるものの磁場中では $10^{2} \mathrm{~A} / \mathrm{cm}^{2}$ 程 度ときわめて低いといら問題がある。粒界での弱結合 を改善し, 高電流密度化を図るには, 結晶粒と結晶粒 間の結合状態を改善する必要があり，それには配向化 と緻密化を同時に達成することが有効と考光られる。 酸化物超電導体の配向化方法は方向性凝固法 ${ }^{17,19)}$, 磁 場中振動法 ${ }^{15)}$ 亿大別される。このうち, 方向性凝固法 による線材作製の試みについては前報で報告した ${ }^{19}$ 。 そこで, 本研究ではタリウム系テープ状線材にプレス 加工法を適用し, 緻密化による結晶粒界弱接合の改善 効果を検討した。

\section{2. 実験方法}

本研究では, タリウム系超電導粉末を充填した合金 パイプを線引きー圧延加工法によってテープ形状とし た後, プレス加工と熱処理を繰返し行い, 加工熱処理 条件と超電導特性の関係を調査した。まず, 用いた粉 末について述べる。

\section{1 超電導粉末の合成}

本研究では, 超電導粉末として $\mathrm{Tl}_{2}\left(\mathrm{Ba}_{0.8}, \mathrm{Sr}_{0.2}\right)_{2}$ $\mathrm{Ca}_{2} \mathrm{Cu}_{3} \mathrm{O}_{10}$ を用い，これに重量で $2 \%$ の銀を添加して 用いた。銀は酸化物超電導体の焼結を促進するととも に，共晶反応を介して高臨界温度相である 2223 相の 生成を促進する効果がある18)。粉末合成方法の詳細に ついては，すでに報告されているので省略する201。

\section{2 線材試料の加工方法}

テープ状線材の加工方法を Fig. 1 亿示す。金属被 覆材には, Au-5 Pd 合金パイプ (外径 6 , 内径 5, 長 さ $400 \mathrm{~mm}$ ）を用い，上記超電導体を初期密度） 2.7

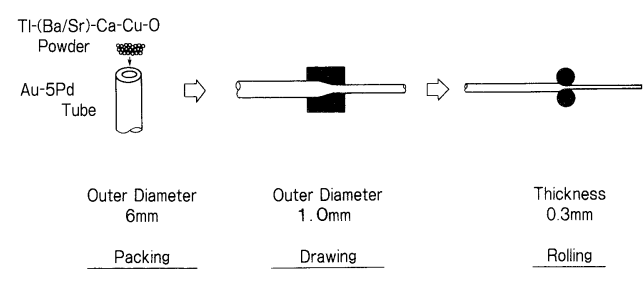

Fig. 1 Fabrication process of tape-shaped wire.

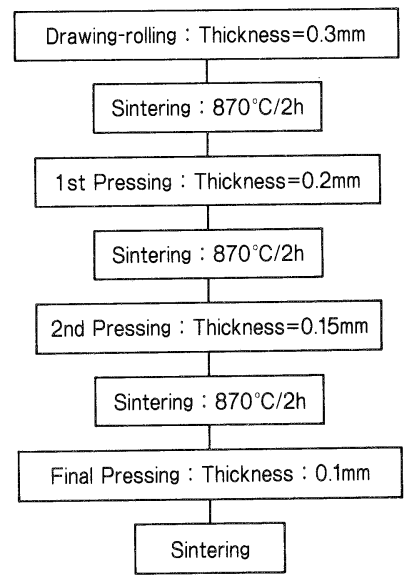

Fig. 2 Experimental procedure of pressing.

$\mathrm{g} / \mathrm{cm}^{2}$ で充填し，これをドローベンチにて外径 1.0 $\mathrm{mm}$ まで線引き加工後, ロール径 $110 \mathrm{~mm}$ の冷間王 延機にて圧延し, 厚さ $0.3 \mathrm{~mm}$, 幅 $2 \mathrm{~mm}$, 長さ $2 \mathrm{~m}$ のテープ状に加工した。このテープ状線材を長さ 40 $\mathrm{mm}$ の短冊状に切断し, 以後熱処理とプレス加工を繰 返して, 最終的に0.1 0.2 mm 厚さとした。プレス 加工条件を Fig. 2 にまとめて示す。なお，プレス用 には直径 $50 \mathrm{~mm}$ の超硬合金製の金型を用いた。

\section{3 評価方法}

試料の微細組織の評価は, 断面組織の偏光顕微鏡観 察ならびに走查型電子影微鏡 (Scanning Electron Microscopy：以下 SEM と略す）拈よび付属のエネルギ 一分散型X線分析計 (Energy Dispersive X-ray Spectroscopy：以下 EDX と略す), 透過電子顕微鏡 (Transmission Electron Microscopy: 以下 TEM と略 す）にて行った。また, 臨界温度 (以下 $T_{\mathrm{c}}$ と略す) および臨界電流密度（以下 $J_{\mathrm{c}}$ と略す）の測定には 4 端子抵抗法を用いた。

また, $J_{\mathrm{c}}$ 測定後, 試料の磁化特性を振動試料型磁力 計 (Vibrating Sample Magnetometer: 以下 VSM と 略す）で評価した。

\section{3. 結果と考察}

\section{1 プレス加工の効果}

Fig. 3 にプレス加工に伴う線材の横断面組織変化を 示す。図からプレス加工の繰返しによって線材の高密 度化が進行していく椂子がわかる。また，プレスによ って超電導体/シース界面が不均質になっている。

Fig. 4 は熱処理条件 $870 \mathrm{C} / 2 \mathrm{~h}$ に打けるプレス回数 と $J_{\mathrm{c}}$ の関係を示す。プレス線材の $J_{\mathrm{c}}$ はプレス加工 


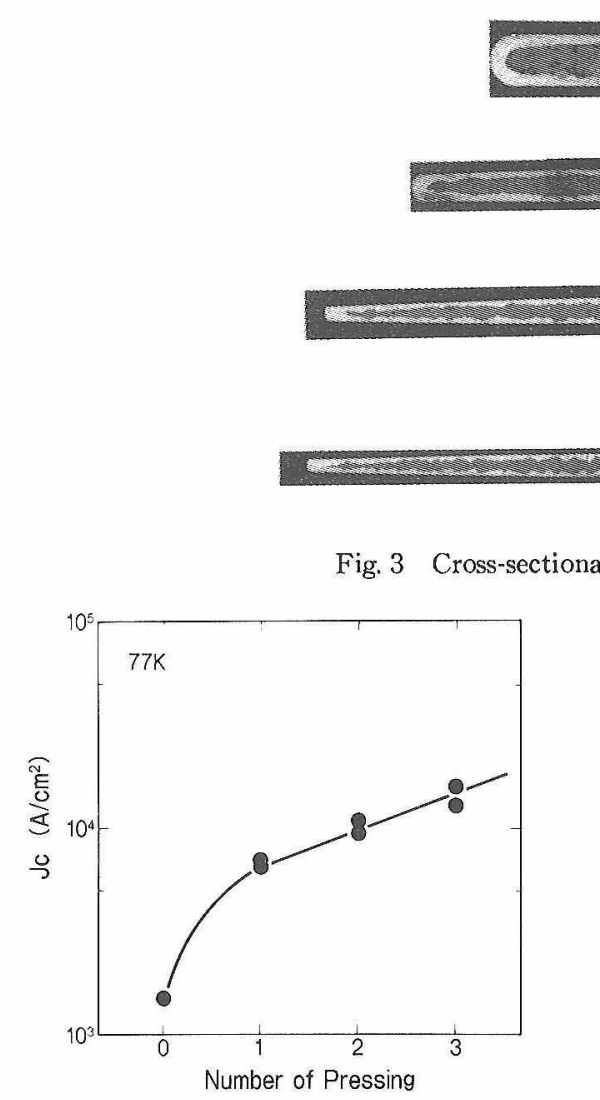

Fig. 4 Relationship between $J_{\mathrm{c}}$ and the number of pressing.

の進行とともに增加する。これは，プレスと熱処理の 繰返しによって線材コアの高密度化が進んだことを反 映した結果と思われる。最高の $J_{0}$ 值は 3 回ブレス時 で $15,300 \mathrm{~A} / \mathrm{cm}^{2}$ に達した。以上から，プレス加工は テープ状線材の高電流密度化に有効な手法であること がわかった。ミクロ組織と $J_{0}$ の関係については 3.3 節で再度検討する。

\section{2 唂処理条件の検討}

前節で述べたよらにプレス加工の有效性が明らかと なったので，次に，プレス線材の熱処理に伴ら組織変 化と $J_{\mathrm{c}}$ の関係について検討した。

Fig. 5 はプレス加工後の熱好理時間を 2 時間と一定 にし，熱処理温度を変化させたときの $J_{\mathrm{c}}$ と熱処理温 度の関係を示す。 $J_{\mathrm{e}}$ は熱処理温度 $830 \sim 880^{\circ} \mathrm{C}$ 付近に 極大值をもち，900 C 以上和よび $800{ }^{\circ} \mathrm{C}$ 以下では低下 する傾向にある。 $J_{\mathrm{c}}$ の最高值は $15,900 \mathrm{~A} / \mathrm{cm}^{2}\left(840{ }^{\circ} \mathrm{C}\right.$ $/ 2 \mathrm{~h}$ 処理）であった。この傾向は压延テープの熱処理 条件について報告した前報の結果 ${ }^{14)}$ とほぼ同じであ
Pressed

\section{$0.2 \mathrm{~mm} \quad 3$ times}



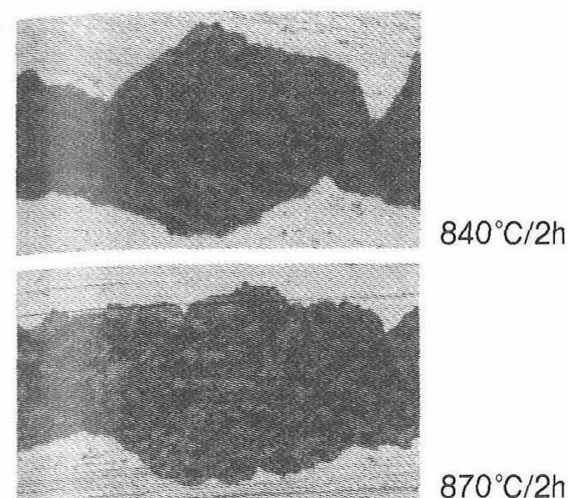

$870^{\circ} \mathrm{C} / 2 \mathrm{~h}$
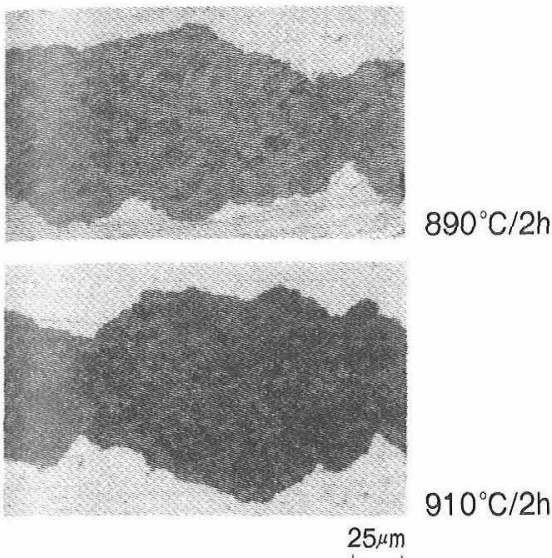

Fig. 6 Optical micrographs of tape-shaped wire with various heat-treatment conditions (cross-sectional view).

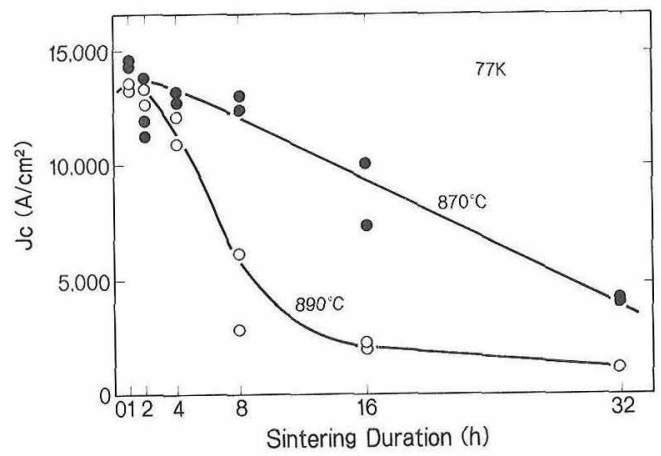

Fig. 7 Relationship between $J_{c}$ and sintering duration.

低下する。Fig. 8 に熱処理過程に批ける線材の横断面 組織変化を示す。図から $890^{\circ} \mathrm{C} て ゙ は ~ 4$ 時間以上で，ま た， 870 C では 16 時間以上で明膫に板状結晶の成長 が認められ，同時に $J_{\mathrm{c}}$ 子低下し始める。また，890 C $/ 32$ 時間処理では, 超電導体/シース界面に超電導 体の分解生成物と思われる異相の析出が観察された。

Vol. 25 No. 3 (1990)

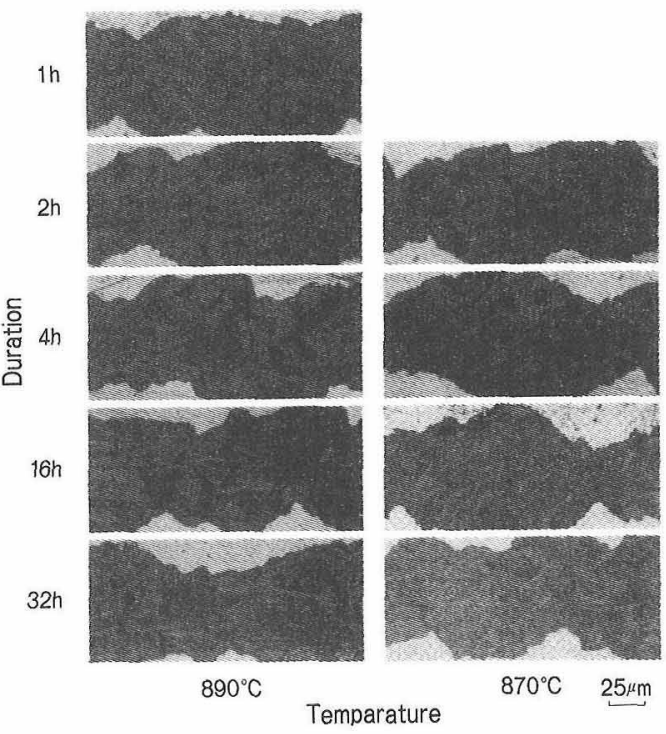

Fig. 8 Optical micrographs of tape-shaped wire with various heat-treatment conditions (cross-sectional view).

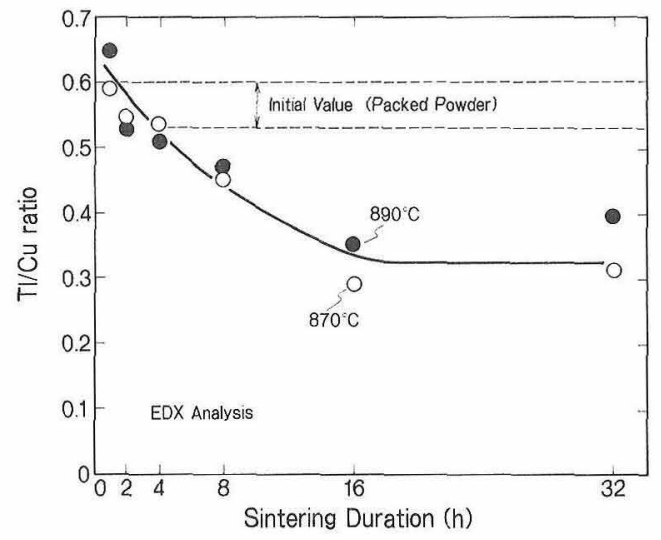

Fig. 9 Relationship between sintering duration and $\mathrm{Tl} / \mathrm{Cu}$ ratio.

以上の事実から，板状結晶は超電導相が（部分）溶融 し，その液相を介して成長したと考えられる。Fig. 9 に EDX 分析による超電導体コア部の $\mathrm{Tl} / \mathrm{Cu}$ 比々熱 処理時間の関係を示す。図から, 熱処理時間の経過と ともに線材中のタリウムが減少して行くことがわかる が，タリウムの蒸発量は熱処理時間に強く依存してお り，一方，温度の影響は比較的小さい。したがって， Fig. 8 に示した $J_{0}$ と熱処理時間の関係は, タリウム の蒸発による特性劣化の影響の久でなく, Fig. 9 に示 した結晶の成長過程と何らかの関係があると推察され る。この事実は先に熱処理温度について倹討した前項 


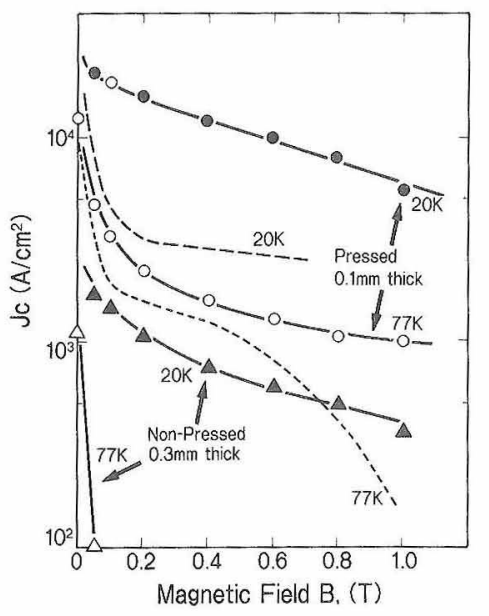

Fig. 10 Magnetic field dependence of $J_{\mathrm{o}}$ with various processing. Broken lines indicate previous work for rolled tape with a thickness of $0.1 \mathrm{~mm}$.

の結果ともよく一致する。

\section{3 ブレス線材の微細組織と超電導特性}

3.1 出よび 3.2 節で述べたようにプレス加工した線 材を適切な熱処理条件で処理すれば液体空素温度にお いて $10^{4} \mathrm{~A} / \mathrm{cm}^{2}$ オーダーの高い電流密度を安定して得 ることが可能である。そこで, 以下では, 熱処理条件 を $870^{\circ} \mathrm{C} / 2 \mathrm{~h}$ と一定にしたとさの微細組織と超電導特 性の関係を詳細に検討した。

Fig. 10 はプレス線材と Fig. 2 に扣けるプレス前の 压延テープ線材（厚さ $0.3 \mathrm{~mm}$ ）の $77 \mathrm{~K}$ および $20 \mathrm{~K}$ 飞怙ける $J_{0}$ の磁場依存性を示す。比較のために 0.1 $\mathrm{mm}$ まで圧延した従来の線材の値を破線で記した ${ }^{14)}$ 。 図から，プレス線材の磁場中の $J_{0}$ はプレス前の圧延 線材に比べて著しく向上し, 従来線材ょりも優れてい
る。さらに注目すべきことは，Jo磁場依存性がプ レス加工の有無で大きく異なる点である。このこと は，プレス加工による高密度化が，たん電流パスを 增加させるばかりでなく，粒界接合性の向上，あるい はピンニングに寄与することを示唆していると解釈で きる。

Fig. 11 ヒプレス線材拈よび压延テープ線材の $20 \mathrm{~K}$ 飞和梳磁化曲線を示す。図中の数字はテープ面と印 加磁場とのなす解度である。図から明らかなように， プレス線材の磁化曲線は, 明らかとプレス前の王延線 材に比べてヒステリシスが増大している。とくに，需 磁場近傍での増大が著しい。高磁場倒の磁化は両者同 程度であるから，プレス線材の低磁場側にみられる大 きなとステリシスの増加は，扰もに結晶粒界部での弱 接合の改善，ぬたは，陷による磁束ピンニングを反 映した結果と考光られる。来た，ヒステリシス曲線 は，磁場方向によってその形が変化している。この結 果は, 紹晶粒間を流孔る電流ループの異方性を反映し な絬果と思われる。すなわち，結晶粒間の結合の強い
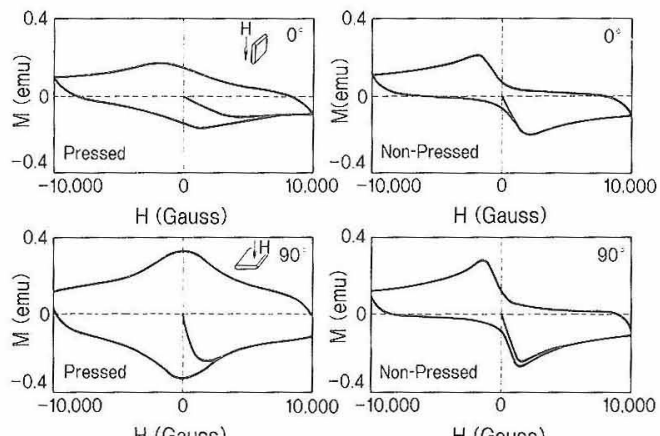

Fig. 11 Comparison of magnetization curves of pressed tape with non-pressed tape.

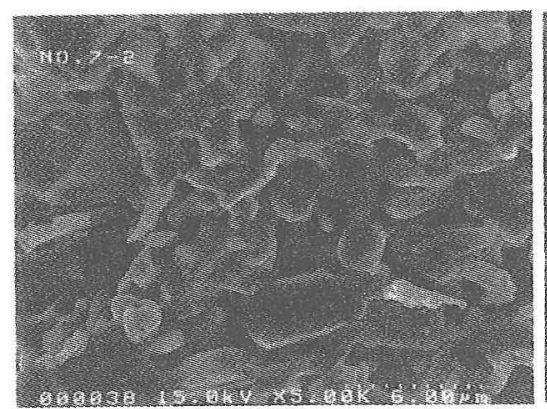

(a)

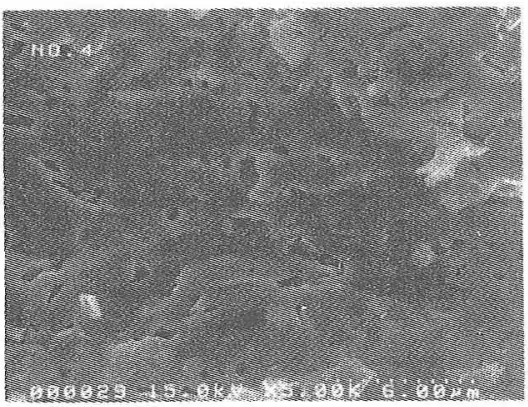

(b)
$2 \mu \mathrm{m}$

Fig. 12 SEM images of fractured core surfaces of tape-shaped wire.

(a) non-pressed, (b) pressed. 


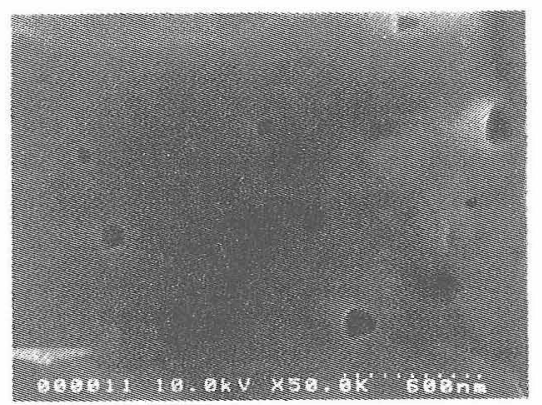

$0.2 \mu \mathrm{m}$

Fig. 13 SEM image of fractured core surface of tape-shaped wire (pressed).

プレス線材は，テープ面に浻って，見かけ上大きな電 流ループを形成するため，磁場方向の影響を受けやす いと推察される。諳細については，今後さらに検討し て行きたい。

Fig. 12 に $870^{\circ} \mathrm{C} / 2 \mathrm{~h}$ 焼成後のプレス線材および压 延線材の横断面 SEM 像を示す。図から，プレス線材 は圧延線材に比べて，著しく繳密度が向上しているこ とがわかる。プレス線材の結晶粒界部分を辣細に観察 した結果を Fig. 13 に示す。破面観察を行ったにもか かわらず，明瞭な粒界が明らかでないのが特徴的であ る。また，結晶粒界に微小なポアが観察され，その大 ささは $0.1 \sim 0.3 \mu \mathrm{m}$ 程度であった。Fig. 14 に本線材 の TEM 観察結果を示す。 SEM で観察されたポアの ほか結晶粒内に無数の積層欠陥が観察された。以上の 組織的特徵を総合すると, プレス圧延加工した線材が 高い $J_{\mathrm{c}}$ を有する原因は, 主として結晶粒間の接合性 が改善されたことによる粒界弱結合の軽減と思われる が，粒界掞よび粒内に钼察される無数の炎陥構造も磁 束のピン止め点として奇与している可能性がある。
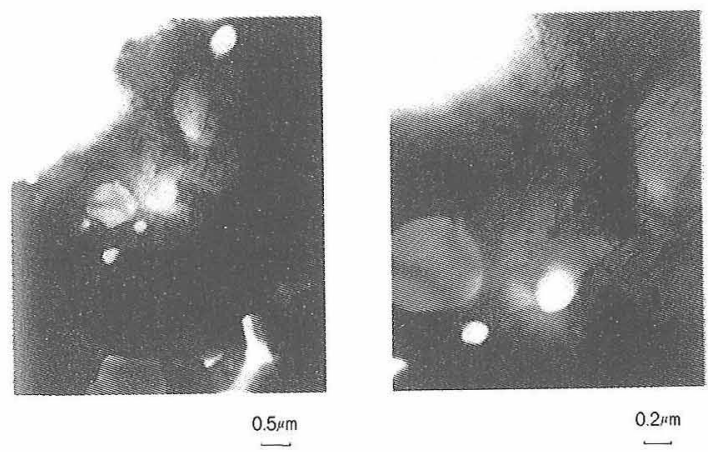

Fig. 14 TEM images of T1-2223 core of tapeshaped wire (pressed).

\section{4. 結論}

タリウム系テープ状線材にプレス加工を試み, 高密 度化・結晶粒界接合の改善による高電流密度化を検客 した。その結果, 以下の結論を得た。

a) プレス加工した線材で， $J_{\mathrm{c}}=15,900 \mathrm{~A} / \mathrm{cm}^{2}(77$ $\mathrm{K}, 0 \mathrm{~T}), 1,100 \mathrm{~A} / \mathrm{cm}^{2}(77 \mathrm{~K}, 1 \mathrm{~T})$ を得た。

b）プレス線材は圧延線材に比較して, 零磁場中 の $J_{\mathrm{c}}$ が高いばかりでなく, 磁場依存性も改善されて いる。

c）プレス線材の高 $J_{\mathrm{c}}$ 化の原因は, 高密度化に よる粒界弱結合の改善と, 微細欠陥の導入による磁束 のピン止めの相乗効果と推察される。

\section{参䓔 文 献}

1) M.K. Wu, J.R. Ashburn, C.J. Trong, P.H. Hor, R.L. Meng, L. Gao, Z.J. Hung, Y.Z. Wang and C.W. Chus: Phys. Rev. Lett. 58 (1957) 908

2) H. Maeda, Y. Tanaka, M. Fukutomi and T. Asano: Jpn. J. Appl. Phys. 27 (1988) L 209

3) Z.Z. Sheng, A.M. Herman, A. El Ali, C. Almasan, J. Estrada and T. Datta: Phys, Rev. Lett. 60 (1987) 937

4）戸叶一正：日本金属学会報 26（1987）980

5) K. Watanabe, N. Kobayashi, H. Yamane, H. Kurosawa, T. Hirai, H. Kawabe and Y. Muto: Jpn. J. Appl. Phys. 28 (1989) L 1417

6) S. Jin, R.C. Sherwood, R.B. Van Dover, T. H. Tiefel and D.W. Jornson, Jr.: Appl. Phys. Lett. 51 (1987) 203

7) D. Dimos, P. Chaudhari, J. Mannart and F. K. Le Goues: Phys. Rev. Lett. 61 (1988) 219

8）北沢㕕一：応用物理 58 (1989) 690

9）岡田道哉ら：超電導物質化学シンポジウム講演 要旨集, 日本化学会 (1987) 52

10) S. Matsuda, M. Okada, T. Morimoto, T. Matsumoto and K. Aihara: Mat. Res. Soc. Symp. Proc. 99 (1988) 695

11) M. Okada, A. Okayama, T. Morimoto, T. Matsumoto, K. Aihara and S. Matsuda: Jpn. J. Appl. Phys, 27 (1988) L 185

12) T. Matsumoto, M. Okada, A. Okayama, T. Morimoto, K. Aihara and S. Matsuda: World Congress on Superconductivity, World Scientific, Singapore (1988) 321

13) M. Okada, A. Okayama, T. Matsumoto, K. Aihara, S. Matsuda, K. Ozawa, Y. Morii and S. Funahashi: Jpn. J. Appl. Phys. 27 (1988) L 1715 
14) M. Okada, R. Nishiwaki, T. Kamo, T. Matsumoto, K. Aihara, S. Matsuda and M. Seido: Jpn. J. Appl. Phys. 27 (1988) L 2345

15) Y. Morii, S. Funahashi, K. Ozawa, M. Okada, T. Matsumoto, K. Aihara and S. Matsuda: Jpn. J. Appl. Phys. 28 (1989) L 618

16) T. Matsumoto, M. Okada, R. Nishiwaki, T. Kamo, K. Aihara, S. Matsuda, M. Seido, K. Ozawa, Y. Morii and S. Funahashi: ISTEC Workshop on Superconductivity Oiso ISTEC (1989) 111

17) M. Okada, T. Yuasa, T. Matsumoto, K. Ai- hara, M. Seido and S. Matsuda: Proc. 2nd Int. Symp. on Superconductivity, ISTEC, to be published

18) P.E.D. Morgan, M. Okada, T. Matsumoto and A. Soeta: Proc. 2nd Int. Symp. on Superconductivity, ISTEC, to be published

19) M. Okada, T. Yuasa, T. Matsumoto, K. Aihara, M. Seido and S. Matsuda: Mat. Res. Soc. Symp. Proc., to be published

20) A. Soeta, T. Suzuki, S. Takeuchi, T. Kamo, K. Usami and S. Matsuda: Jpn. J. Appl. Phys. 28 (1989) L 1186 